\title{
Evolution of forest soil properties after liming with a by-product derived from a sugar beet mill
}

\author{
Isabel M. González ${ }^{1}$, Juan F. Gallardo², José A. Egido ${ }^{1}$ and José J. Obrador ${ }^{3}$
}

\begin{abstract}
Deciduous oak coppices (Quercus pyrenaica Willd.) of the "Sierra de Gata" mountains (central western Spain) are located on acid rocks and subjected to annual rainfall higher than $700 \mathrm{~mm}_{\text {year }}{ }^{-1}$. Accordingly, the soils are acidic (soil pH is often below 5.0) and feature the presence of $\mathrm{Mn}^{2+}$ and $\mathrm{Al}^{3+}$ in the exchangeable complex. The aim of the present study was to assess the response of these soils to the addition of a lime residue from a sugar beet mill to reach pH values close to 7.0 and 6.0 with in situ and in vitro experiments, respectively. Initially, the quality of the lime by-product was evaluated, which showed content close to $75 \% \mathrm{CaCO}_{3}$. Based on that analysis, calculations were accomplished to determine the dose of lime by-product necessary for achieving the targeted soil $\mathrm{pH}$. We first performed an in vitro liming experiment, incubating $0.50 \mathrm{~kg}$ soil $\left(0-20 \mathrm{~cm}\right.$ layer) with $23.92 \mathrm{~g} \mathrm{CaCO}_{3} \mathrm{~kg}^{-1}$ soil $\left(20^{\circ} \mathrm{C}\right.$ and soil moisture equivalent to that of field capacity). Subsequently, another experiment was done adding an equivalent quantity of sub-product in lieu of the pure $\mathrm{CaCO}_{3}$; the factors monitored were: soil pH, exchange acidity, $\mathrm{CEC}$, and exchangeable bases, every $24 \mathrm{~h}$. The in situ experiment was performed in a forest plot located in Western Spain (Navasfrías), liming with 16.0 Mg DM by-product ha ${ }^{-1}$ (September 1999). Soil samples (two depths: 0-10 and 10-20 cm) were taken from both the control and the experimental forest plots for monitoring the liming effect. Sampling dates were September and December 1999; June 2000, January, June and September 2001; October 2002 and 2003, and March 2005). The dissolution of the lime by-product at the laboratory was almost immediate, but the effects in the field occurred approximately 2 years after initial liming, since lime dissolution depends on both the amount and distribution of rainfall and, also, on the application procedure.
\end{abstract}

Keywords: Forest ecosystem, Oak stands, Quercus pyrenaica, Acid soils

\section{Background}

A deep knowledge of the behavior of forest systems is necessary prior to any action of revaluation or improvement of productivity to achieve sustainable development $[1,2]$. Traditionally, studies on forest ecosystems (in general, on acid soils; [3]) have been directed to, in general, a practical point of view, mainly toward achieving high yields [4] and/or other specific outcomes without considering basic aspects, such as preventing soil degradation, reducing erosion risks, etc., which may have negative effects on forest productivity in the long term. When

\footnotetext{
*Correspondence: juanf.gallardo@csic.es

${ }^{2}$ C.S.I.C., IRNASa, Cordel de Merinas 40, Salamanca 37080, Spain

Full list of author information is available at the end of the article
}

forest productivity drops, a social consequence is the human abandonment of the affected territories, usually linked to the effect of a progressive acidification of soils [5].

Deciduous oak forests (Quercus pyrenaica Willd.) are abundant in the western portion of the Iberian Peninsula [6], especially at sites where rainfall is higher than $800 \mathrm{~mm} \mathrm{year}^{-1}$; they are installed on acid soils (soil pH is often below 5.0), developed on acidic rocks of the Precambrian Era (shale-greywacke complex, affected by regional and contact metamorphisms; [7]).

Studies regarding better knowledge of these forest ecosystems have been previously performed (e.g., [1, $8,9,10])$, mainly focused on biogeochemical cycles of nutrients. Gallardo et al. [8] observed different values of 
production of these deciduous oak forests according to different areas; these differences seemed to be inversely related to the amount of annual rainfall, which caused differences in soil acidity. It is well known that when the soil $\mathrm{pH}$ is lower than $4.0, \mathrm{Mn}^{2+}$ and $\mathrm{Al}^{3+}$ cations exist in soluble forms [11], increasing their plant availability and causing toxicity, inhibiting forest growth [12]. Furthermore, other works $[13,14,15]$ showed the lack of response of these forests to the addition of $\mathrm{N}$ and $\mathrm{P}$ fertilizers.

Runge and Rode [16] pointed out that adding products containing $\mathrm{Ca}$ to acid soils caused benefits to plant growth, due to the increase of soil $\mathrm{pH}$, exchangeable $\mathrm{Ca}^{2+}$, and $\mathrm{P}$ availability; in addition to this, an increase in the mineralization rate of the soil organic matter (SOM) was also observed. Bakker and Nys [17] studied the effects of liming on the evergreen Holm oak (Q. ilex) in soils with different fertility degrees, finding that (within the range of soil fertility of the area considered in the study) moderate doses of lime increased the biomass of fine roots, both in the topsoil and in the sub-superficial horizons, also favoring the availability of $\mathrm{Ca}$ and $\mathrm{Mg}$, but not that corresponding to $\mathrm{P}$ and $\mathrm{K}$. The effect of liming on some fractions of SOM and soil quality has been also considered $[18,19]$.

Some authors have investigated the effect of limestone industrial wastes (for example, by-products obtained from paper pulp and steel industries) on forest soils, using them as amendments, given the importance of that re-use in the reduction of environmental impacts $[20,21$, $22,23]$.

Some by-products resulting from the process of bleaching of sugar extracted from the sugar beet (Beta vulgaris L. var. vulgaris subspecies, Altissima), obtained during the process of the sugar crystallization by carbonation, have been also used as liming material. This sub-product usually contains $75 \% \mathrm{CaCO}_{3}$ and has a basic $\mathrm{pH}$. This calcic material is difficult to handle due to its high hygroscopicity, which decreases its practical use elsewhere; but it could be used as liming material [24]. The addition of this by-product to soil meets two objectives: (1) eliminating this residue; and [17] raising the soil $\mathrm{pH}$ of the acid forest ecosystems.

The objective of this study was to assess, through a multi-year monitoring, the soil response after addition of a lime by-product to a forest soil; this by-product, rich in calcium carbonate, was obtained from a local sugar mill.

The initial hypothesis was that the addition of calcium carbonate to acid soils would increase the soil $\mathrm{pH}$, decreasing the presence of exchangeable $\mathrm{Al}^{3+}$ that negatively affects forest production.

In performing this study, firstly, the properties of the limestone by-product were analyzed. Later, we studied in vitro the effects of the addition of this by-product to a sample of the acid forest soil selected. Finally, we followed the effects, at medium term, of this lime residue added on the soil surface layer of the aforementioned forest soil.

The selected forest system was a deciduous oak forest of Q. pyrenaica located at the 'Sierra de Gata' Mountains (western Spain).

\section{Methods}

\section{Study site}

The study site (named Navasfrías) is located in the Spanish Central System $\left(40^{\circ} 2^{\prime} 40^{\prime \prime} \mathrm{N}, 3^{\circ} 0^{\prime} 50^{\prime \prime} \mathrm{W}\right.$; Fig. 1), specifically in the Spanish district named "El Rebollar" (North Versant of the 'Sierra de Gata' Mountains, province of Salamanca, Spain), at an altitude of $960 \mathrm{~m}$ a.s.l. The selected plot was representative of this forest ecosystem and had a surface of $0.78 \mathrm{ha}$; it was fenced to prevent the entry of wild animals and/or domestic livestock.

The climate is Mediterranean, temperate, and sub-humid. The registered mean annual rainfall is $1580 \mathrm{~mm}$ year $^{-1}$ [13], with a mean annual temperature of $10.4{ }^{\circ} \mathrm{C}$. The rainy season during $1999 / 00$ was dry (793 mm year ${ }^{-1}$ ), while the corresponding 2000/2001 season was very wet $\left(2186 \mathrm{~mm} \mathrm{a}^{-1}\right)$; the $2001 / 02$ cycle was almost normal (1412 $\mathrm{mm} \mathrm{year}^{-1}$ ), and 2002/2003 season had a very wet fall/winter (similar to 2000/01). There is a wide inter-annual variation in rainfall distribution, but there is always a dry summer.

The climax vegetation is the deciduous oak forest $(Q$. pyrenaica Willd.). This ecosystem can be described as a regular coppice, about $60-80$ years old, with a relatively high tree density ( 820 trunks per ha ${ }^{-1}$ ), scarce productivity, and with intermittent cattle grazing, mostly during late spring and summer.

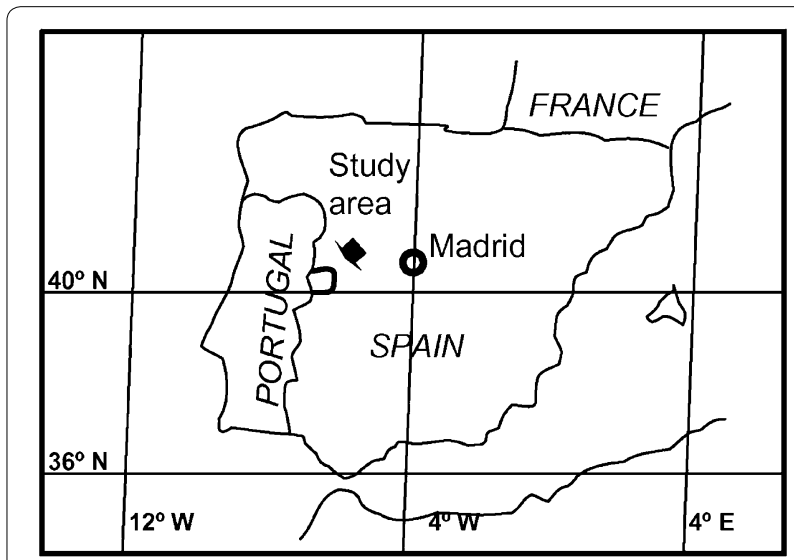

Fig. 1 Location of the experimental forest plot of Navasfrías (Western Spain) 
This forest has a limited aboveground production $\left(2.6 \pm 0.16 \mathrm{Mg} \mathrm{DM} \mathrm{ha}{ }^{-1}\right.$ year $\left.^{-1}\right)$, compared to other nearby deciduous oak forest sites [1]; for example, measured productivities of closer oak stands are: $3.5 \pm 0.28 \mathrm{Mg} \mathrm{DM}$ ha $^{-1}$ year $^{-1}$ in the El Payo plot, $2.8 \pm 0.23 \mathrm{Mg} \mathrm{DM} \mathrm{ha}{ }^{-1}$ year $^{-1}$ in Villasrrubias, and $4.1 \pm 0.27 \mathrm{Mg} \mathrm{DM} \mathrm{ha}^{-1}$ year $^{-1}$ in Fuenteguinaldo [1].

A high proportion of this above-ground production $\left(2.60 \mathrm{Mg} \mathrm{DM} \mathrm{ha}^{-1} \mathrm{year}^{-1}\right.$ ) corresponds to leaves $2.1 \pm 0.11 \mathrm{Mg} \mathrm{DM} \mathrm{ha}^{-1}$ year $^{-1}[8]$.

The site is considered a marginal area due to the low economic production and is basically appropriate for purposes of conservation of natural species.

Topographic position defines the soil depth and typography. Dominant soils are cambic Umbrisols [25], equivalent to the association typic Haplumbrepts in the Soil Taxonomy classification system [26] and Leptosols. These Umbrisols are usually deep and have a non-permanent organic layer $O$ of litter accumulation; a deep and dark $A_{h}$ horizon (thickness $\geq 40 \mathrm{~cm}$ ) with low bulk density $\left(0.60-0.70 \mathrm{Mg} \mathrm{m}^{-3}\right)$; and a $B_{w}$ horizon, sometimes not well developed or detectable (masked by the high content of SOM; $[27,28])$, increasing the bulk density to $1.0 \mathrm{Mg} \mathrm{m}^{-3}$ (measured to $-50 \mathrm{~cm}$ soil depth) downward.

\section{Liming material}

To know the suitability as liming material of the lime residue by-product obtained from the sugar industry, the analysis of inorganic and organic $\mathrm{C}$ was previously carried out and, hence, the $\mathrm{CaCO}_{3}$ equivalent content was estimated. The measurement of $\mathrm{C}$ was performed using a Carmhograph 12 (Wösthoff).

During the manufacturing process, the added $\mathrm{CaCO}_{3}$ is mixed with organic waste (OR). Therefore, the organic $\mathrm{C}$ (Co) of the by-product of limestone was also determined adding $\mathrm{HCl} 1.0 \mathrm{~N}$ to it and later drying at $200{ }^{\circ} \mathrm{C}$ for $2 \mathrm{~h}$. Total $\mathrm{C}(\mathrm{Ct}=$ inorganic $\mathrm{C}+$ organic $\mathrm{C})$ was obtained by determining directly the $\mathrm{C}$ in the lime by-product sample. Hence, the content of inorganic $\mathrm{C}(\mathrm{Ci})$ was obtained by subtracting the Co determined from the $\mathrm{Ct}$; the $\mathrm{CaCO}_{3}$ content of the by-product can be obtained by simple calculations.

The moisture content of the lime residue was also determined, by the weight loss at $110^{\circ} \mathrm{C}$ in an oven.

\section{Experiment design}

After the characteristics of the sugar industry sub-product were determined in the laboratory as valuable for liming, this material was spread on the described experimental plot (located at Navasfrías, close to $1.0 \mathrm{ha}$ ), and the main soil properties were monitored during a long period (from 1999 to 2005).
From this experimental forest plot, a subplot (of about $3000 \mathrm{~m}^{2}$ ) was segregated to be limed and with soil samples taken systematically as later indicated, avoiding border effects.

\section{Requirement of lime of acid soils}

Calculation of the dose of lime to be added (lime requirement: $R_{\text {lime }}$ ) was carried out according to the methods described by Guitián and Carballas [29] and Cochrane et al. [30]:

$$
\begin{aligned}
& \text { Subproduc }(\mathrm{MgCaO}) \mathrm{ha}^{-1} \\
& \quad=8.4 \frac{\left(\mathrm{pH}_{\text {final }}-\mathrm{pH}_{\text {subp }}\right)}{\left(7.0-\mathrm{pH}_{\text {subp }}\right)}(7.0-5.7) .
\end{aligned}
$$

To achieve the soil $\mathrm{pH}=6.0$ :

$$
\begin{aligned}
\text { Subproduct }(\mathrm{Mg}, \mathrm{CaO}) \mathrm{ha}^{-1} & =8.4 \frac{(6.0-4.3)}{(7.0-4.3)}(7.0-5.7) \\
& =6.8(\mathrm{MgCaO}) \mathrm{ha}^{-1}
\end{aligned}
$$

For attaining the soil $\mathrm{pH}=7.0$ :

$$
\begin{aligned}
\text { Subproduct }(\mathrm{MgCaO}) \mathrm{ha}^{-1} & =8.4 \frac{(7.0-4.3)}{(7.0-4.3)}(7.0-5.7) \\
& =10.75(\mathrm{MgCaO}) \mathrm{ha}^{-1} .
\end{aligned}
$$

The value 5.7 is the soil $\mathrm{pH}$ after the addition of the buffer calcium p-nitrophenol-acetate.

According to calculations [30], $32.20 \mathrm{~g}$ of the lime byproduct fertilizing per kilogram of soil is required to achieve soil pH 7.0.

\section{Soil sampling}

For this soil study, soil samples were taken from the plot of Navasfrías at two soil depths $(0-10$ and $10-20 \mathrm{~cm})$, because these layers are more sensitive to the liming impacts. We conformed composite soil samples (for each depth) mixing 15 soil subsamples, using a cylindrical auger at random to obtain a representative sample [31].

For the in vitro study, only a soil sample was taken at a unique depth of $0-20 \mathrm{~cm}$.

Reference soil (not limed) samples were taken in June 1996, December 1999, September 2001, and March 2005. In the limed plot, soil samples were taken in December 1999, June 2000, January, June and September 2001, October 2002 and 2003, and March 2005.

\section{Response (in vitro) of soil to the lime by-product}

Soil samples $(0.50 \mathrm{~kg}$; soil depth $0-20 \mathrm{~cm})$ were homogenized and then incubated for $72 \mathrm{~h}$ with and without application of the limestone by-product, according to the dose calculated as described previously. 
To evaluate the response of soil to the liming material, the soil pH (with and without addition of the limestone by-product) was measured during the incubation in vitro, comparing the results obtained.

The response of the soil sample to the addition of pure $\mathrm{CaCO}_{3}$ (used as reference; $23.9 \mathrm{~g} \mathrm{CaCO}_{3} \mathrm{~kg}^{-1}$ soil, equivalent to $19.3 \mathrm{Mg} \mathrm{CaCO}_{3} \mathrm{ha}^{-1}$ ) was also tested.

The temperature to which the experiment was conducted was $20^{\circ} \mathrm{C}$, maintaining a soil moisture equivalent to the field capacity.

Experiments were performed in duplicate. In each case, three bottles were placed for each dose of lime (by-product or pure $\mathrm{CaCO}_{3}$; i.e., by triplicate); then, $n=2 \times 3=6$ repetitions in total.

Every $24 \mathrm{~h}(24,48$, and $72 \mathrm{~h})$, soil samples were taken from flasks (at random) and analyzed. The selected soil parameters were: soil $\mathrm{pH}(\mathrm{KCl}$ in saturated paste; and soil:water 1:2.5); exchangeable acidity by extraction with $\mathrm{KCl} 1.0 \mathrm{~N}$; cation exchange capacity (CEC) and exchangeable bases using neutral ammonium acetate [32].

\section{Liming of forest soil (in situ)}

On September 5, 1999, the lime by-product was spread superficially on the experimental subplot selected, just before the beginning of the autumnal rain season. The planned soil $\mathrm{pH}$ to be reached in the field was 6.0. It is not advisable for lime to reach a soil $\mathrm{pH}$ of 7.0 , due to the high amount of lime by-product (25.6 $\mathrm{Mg} \mathrm{DM} \mathrm{ha}^{-1}$ ) needed to achieve it, as this by-product tends to form lumps (given its high hygroscopicity) at the soil surface hindering its dissolution.

To achieve this theoretical soil $\mathrm{pH}$ of $6.0,16.0 \mathrm{Mg}$ lime by-product $\mathrm{ha}^{-1}$ was added, according to the dose calculated, as previously indicated, using the formula proposed by Guitian and Carballas [29], bearing in mind the purity and moisture of this by-product $\left(75 \% \mathrm{CaCO}_{3}\right.$ and $14 \%$ water). That means a net amount added of $12.0 \mathrm{Mg} \mathrm{CaCO}_{3} \mathrm{ha}^{-1}\left(0.48 \mathrm{~kg} \mathrm{Ca} \mathrm{m}^{-2}\right)$. Incidentally, the soil also received a contribution of $0.47 \mathrm{Mg} \mathrm{C} \mathrm{ha}^{-1}$, due to the organic content of the by-product, as indicated above.

\section{Soil analysis}

Soil samples were analyzed according to the routine methods recommended by the WRB-FAO [25]; the selected soil parameters were: soil $\mathrm{pH}(\mathrm{KCl}$ in saturated paste, and soil:water 1:2.5), soil organic C (SOC) determined by dry combustion (Carmhograph 8 Wösthoff), soil total $\mathrm{N}\left(\mathrm{N}_{\text {total }}\right)$ by micro-Kjeldahl, CEC and exchangeable bases by the neutral ammonium acetate method [32]; available $\mathrm{Ca}$ and $\mathrm{K}$ extracted by ammonium acetate, and available $\mathrm{P}$ according to Bray and Kurz [33].

\section{Statistical analysis}

The statistical package S.P.S.S. 12.1 was applied to the data obtained. For the statistical analysis of the evolution in vitro of the soil parameters, a design at random with three treatments and six replicates was implemented.

To know whether there were significant differences $(P<0.05)$, a $t$ test of a small number of samples was applied (after verification of homoscedasticity; test of Levene). Differences between the treatments were tested using the one-way ANOVA followed by a Tukey's HSD post hoc test.

When no significant differences between the variables of both sub-horizons were found, soil samples from the two depths were considered as one unique sample.

\section{Results}

Soil properties (Table 1)

Table 1 presents the soil characteristics of the no-limed forest soil of the plot at Navasfrías; two soil layers $(0-10$ and $10-20 \mathrm{~cm}$ ) are considered.

These forest soils have high contents of SOC and acid reaction. The available $\mathrm{P}$ is, in any case, low but variable over time. The exchangeable $\mathrm{Ca}^{2+}$ presents low values in the first soil layer $(0-10 \mathrm{~cm})$ and very low in the second one $(10-20 \mathrm{~cm})$, which correspond to low values of available $\mathrm{Ca}$ at both depths. The exchangeable $\mathrm{K}^{+}$has values ranging from acceptable to low, according to soil depth considered.

\section{Characteristics of the lime by-product (Table 2)}

The moisture of the by-product (dried to $110^{\circ} \mathrm{C}$ ) was around $14.0 \%$.

The content of $\mathrm{Ct}$ of the lime by-product (determination by combustion) was $12 \%$; the content of Co, $3.0 \%$; and $\mathrm{Ci}$ was $9.0 \%$ (Table 2). Accordingly, this by-product had a content of $75 \% \mathrm{CaCO}_{3}$, with $5.0 \%$ organic matter, and $20 \%$ moisture (the rest being inorganic impurities; Table 2).

On the other hand, the content of $\mathrm{CaCO}_{3}$, determined adding $\mathrm{HCl}$ and measuring the $\mathrm{CO}_{2}$ evolved, was $72 \%$; this value is close to that obtained by dry combustion (75\%), after subtracting the $\mathrm{C}$ corresponding to the organic matter.

\section{In vitro evolution of soil parameters (Table 3 )}

Limed soils (either with pure $\mathrm{CaCO}_{3}$ or with lime byproduct) incubated at the laboratory showed significant changes (Table 3 ) in the soil parameters analyzed.

The evolution of the soil $\mathrm{pH}(\mathrm{KCl}$ or soil:water 1:2.5) obtained at 24,48 , and $72 \mathrm{~h}$ showed significant increases, after the addition of both lime products $(0.9$ and 1.4 for the pure $\mathrm{CaCO}_{3}$ and the by-product, respectively). However, $\mathrm{pH} 7.0$ was not achieved (as estimated), attaining 


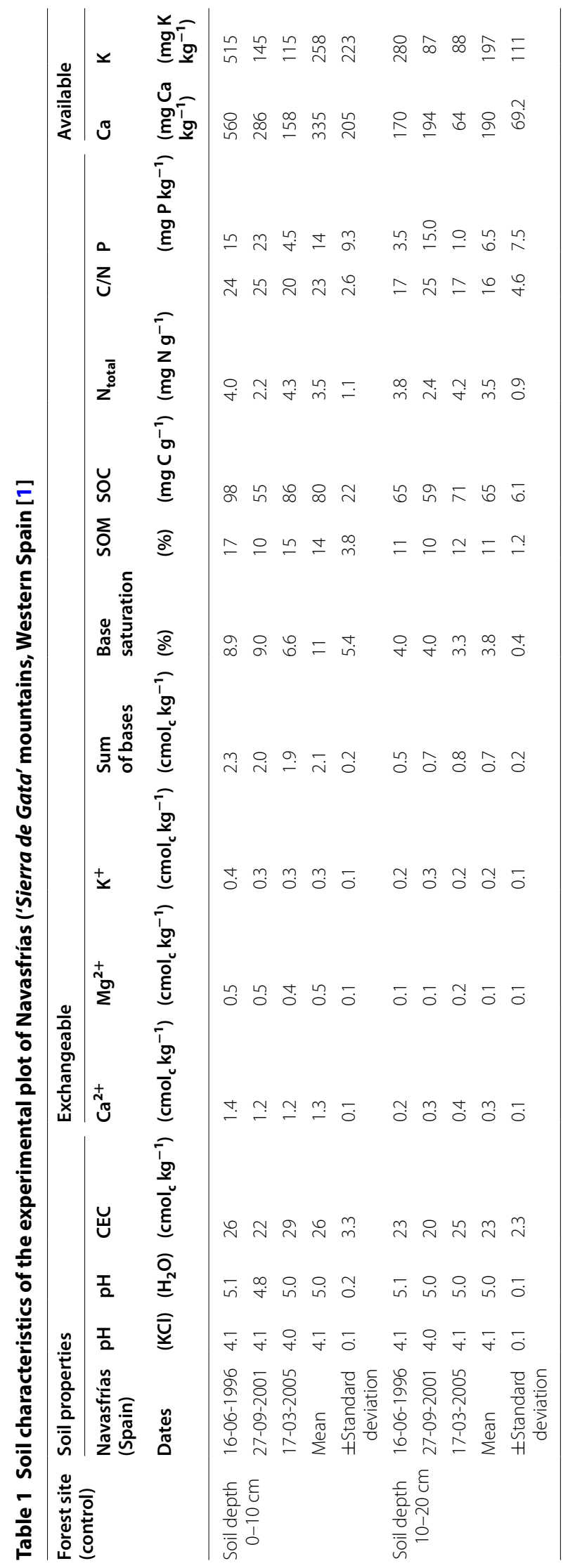


Table 2 Characteristics of the limestone by-product

\begin{tabular}{|c|c|c|c|c|c|c|c|c|c|c|c|c|}
\hline \multirow{2}{*}{$\begin{array}{l}\text { Liming by- } \\
\text { product }\end{array}$} & \multirow{2}{*}{$\begin{array}{l}\text { Moisture } \\
\text { (air dried) } \\
\text { (\%) }\end{array}$} & \multirow{2}{*}{$\begin{array}{l}\text { Bulk density } \\
\left(\mathrm{g} \mathrm{cm}^{-3}\right)\end{array}$} & \multirow{2}{*}{$\begin{array}{l}\mathrm{pH}\left(\mathrm{H}_{2} \mathrm{O}\right) \\
(1: 2.5)\end{array}$} & \multirow{2}{*}{$\begin{array}{l}\text { Electrical } \\
\text { conductivity } \\
\left(\mathrm{dS} \mathrm{m}^{-1}\right)\end{array}$} & \multirow{2}{*}{$\begin{array}{l}\text { Total C } \\
\text { (Ct) }\end{array}$} & \multirow{2}{*}{$\begin{array}{l}\text { Organic C } \\
(\mathrm{Co})(\mathrm{mg} \mathrm{C} \\
\left.\mathrm{g}^{-1}\right)\end{array}$} & \multirow{2}{*}{$\begin{array}{l}\text { Inorganic } \\
\mathrm{C}(\mathrm{Ci})\end{array}$} & \multirow{2}{*}{$\begin{array}{l}\mathrm{CaCO}_{3} \\
\text { (calculated) } \\
(\%)\end{array}$} & \multirow[t]{2}{*}{$P$} & \multirow{2}{*}{\multicolumn{2}{|c|}{$\begin{array}{l}\text { Ca Mg } \\
\text { Available } \\
\left(\mathrm{mg} \mathrm{kg}^{-1}\right)\end{array}$}} & \multirow[t]{2}{*}{ K } \\
\hline & & & & & & & & & & & & \\
\hline Mean $(n=9)$ & 13.6 & 0.8 & 8.2 & 12.5 & 120 & 29.6 & 90.5 & 75.4 & 310 & 6400 & 2025 & 1050 \\
\hline $\begin{array}{r} \pm \text { Standard } \\
\text { deviation }\end{array}$ & \pm 0.5 & N.d. & N.d. & N.d. & \pm 3.4 & \pm 1.2 & \pm 3.3 & \pm 2.8 & N.d. & N.d. & \pm 170 & N.d. \\
\hline
\end{tabular}

N. d. no data

Table 3 Temporal evolution of soil parameters after liming (in vitro; 0-20 cm)

\begin{tabular}{|c|c|c|c|c|}
\hline \multirow{3}{*}{$\begin{array}{l}\text { In vitro experiment } \\
\text { Hor. } A h(0-20 \mathrm{~cm})\end{array}$} & \multirow[t]{3}{*}{ Control } & \multicolumn{3}{|c|}{ Limed samples } \\
\hline & & \multicolumn{3}{|c|}{ Time after liming } \\
\hline & & $24 \mathrm{~h}$ & $48 \mathrm{~h}$ & $72 \mathrm{~h}$ \\
\hline \multicolumn{5}{|l|}{ Limed with pure $\mathrm{CaCO}$} \\
\hline $\mathrm{pH}(\mathrm{KCl})$ & $4.1 \pm 0.1 \mathrm{a}$ & $5.79 \pm 0.01 b$ & $5.79 \pm 0.01 b$ & $5.78 \pm 0.02 b$ \\
\hline $\mathrm{pH}$ (saturated paste) & $4.8 \pm 0.1 \mathrm{a}$ & $6.65 \pm 0.02 b$ & $6.66 \pm 0.02 b$ & $6.64 \pm 0.02 b$ \\
\hline pH (soil:water 1:2.5) & $5.0 \pm 0.1 \mathrm{a}$ & $6.90 \pm 0.01 b$ & $6.90 \pm 0.01 b$ & $6.92 \pm 0.01 c$ \\
\hline $\mathrm{H}^{+}\left(\mathrm{cmol}_{\mathrm{c}} \mathrm{kg}^{-1}\right)$ & $4.0 \pm 0.1 \mathrm{a}$ & $0.20 \pm 0.01 b$ & $0.20 \pm 0.01 b$ & $0.20 \pm 0.01 b$ \\
\hline $\mathrm{Al}^{3+}\left(\mathrm{cmol}_{\mathrm{c}} \mathrm{kg}^{-1}\right)$ & $1.4 \pm 0.1 \mathrm{a}$ & $0.20 \pm 0.1 b$ & Traces & Traces \\
\hline \multicolumn{5}{|l|}{ Limed with lime sub-product } \\
\hline $\mathrm{pH}(\mathrm{KCl} 1: 2.5)$ & $4.1 \pm 0.1 \mathrm{a}$ & $5.30 \pm 0.01 c$ & $5.40 \pm 0.01 c$ & $5.40 \pm 0.01 c$ \\
\hline pH (saturated paste) & $4.8 \pm 0.1 \mathrm{a}$ & $6.25 \pm 0.03 b$ & $6.43 \pm 0.02 b c$ & $6.40 \pm 0.02 b c$ \\
\hline pH (soil:water 1:2.5) & $5.0 \pm 0.1 \mathrm{a}$ & $6.38 \pm 0.01 c$ & $6.59 \pm 0.01 c$ & $6.58 \pm 0.01 c$ \\
\hline $\mathrm{CEC}\left(\mathrm{cmol}_{\mathrm{C}} \mathrm{kg}^{-1}\right)$ & $26.0 \pm 2.0 \mathrm{a}$ & $42.6 \pm 0.4 b$ & $43.3 \pm 0.4 b$ & $43.2 \pm 0.4 b$ \\
\hline Exchangeable $\mathrm{Ca}^{2+}\left(\mathrm{cmol}_{\mathrm{C}^{-1}} \mathrm{~kg}^{-1}\right)$ & $1.2 \pm 0.1 \mathrm{a}$ & $3.7 \pm 0.3 b$ & $3.4 \pm 0.1 b$ & $3.0 \pm 0.2 b$ \\
\hline Exchangeable $\mathrm{Mg}^{2+}\left(\mathrm{cmol}_{\mathrm{c}} \mathrm{kg}^{-1}\right)$ & $0.5 \pm 0.1 \mathrm{a}$ & $0.39 \pm 0.01 b$ & $0.36 \pm 0.02 b$ & $0.36 \pm 0.02 b$ \\
\hline Exchangeable $\mathrm{K}^{+}\left(\mathrm{cmol}_{\mathrm{c}} \mathrm{kg}^{-1}\right)$ & $0.3 \pm 0.1 a$ & $0.09 \pm 0.1 b$ & $0.09 \pm 0.01 b$ & $0.07 \pm 0.02 b$ \\
\hline Base sum $\left(\mathrm{cmol}_{\mathrm{c}} \mathrm{kg}^{-1}\right)$ & $2.0 \pm 0.1 \mathrm{a}$ & $4.2 \pm 0.4 b$ & $3.9 \pm 0.4 b$ & $3.4 \pm 0.4 b$ \\
\hline Base saturation (\%) & 7.7 & 9.9 & 9.0 & 7.9 \\
\hline Exchangeable $\mathrm{H}^{+}\left(\mathrm{cmol}_{\mathrm{c}} \mathrm{kg}^{-1}\right)$ & $4.0 \pm 0.1 \mathrm{a}$ & $0.20 \pm 0.01 b$ & $0.20 \pm 0.01 b$ & $0.20 \pm 0.01 b$ \\
\hline Exchangeable $\mathrm{Al}^{3+}\left(\mathrm{cmol}_{\mathrm{C}} \mathrm{kg}^{-1}\right)$ & $1.4 \pm 0.1 \mathrm{a}$ & $0.20 \pm 0.1 b$ & Traces & Traces \\
\hline
\end{tabular}

slightly lower values (Table 3 ). In any case, $\mathrm{pH}$ values increased more with the pure $\mathrm{CaCO}_{3}$ than with lime byproduct, probably due to the smaller size of particle of the first liming substance.

After the application of the liming material, the soil CEC increased significantly from 26 to $43 \mathrm{cmol}_{\mathrm{c}} \mathrm{kg}^{-1}$ (Table 3) after the first $24 \mathrm{~h}$; thereafter, the statistical analysis showed no significant differences.

In spite of the increase of the soil CEC values, the percentage of saturation did not vary significantly (less than $10 \%$ ), but the exchangeable acidity decreased significantly (of 4.0-0.2 $\mathrm{cmol}_{\mathrm{c}} \mathrm{kg}^{-1}$ ) after the liming treatment (Table 3); also, the exchangeable $\mathrm{Al}^{3+}$ was reduced (from 1.4 to $0.2 \mathrm{cmol}_{\mathrm{c}} \mathrm{kg}^{-1}$ ) after $24 \mathrm{~h}$ and, afterward, to trace values.

Moreover, after adding the liming products, a significant increase in the values of the exchangeable $\mathrm{Ca}^{2+}$ occurred, as well as a decrease of the exchangeable $\mathrm{Mg}^{2+}$, indicating that the former cation is preferred to be adsorbed by the exchangeable complex; the exchangeable $\mathrm{K}^{+}$also decreased by the interference of the dominant exchangeable $\mathrm{Ca}^{2+}$.

\section{Evolution in situ of soil parameters (Tables 4 and 5)}

Tables 4 and 5 show the temporal evolution on-site of some soil parameters after liming (5 September 1999); we have only considered two depths $(0-10$ and $10-20 \mathrm{~cm})$, which are more sensitive to the impact of a superficial liming.

The observed changes in the soil parameters were most noticeable in the soil layer $0-10 \mathrm{~cm}$, but less intense than those observed in the in vitro experimentation (Table 3).

Soil $\mathrm{pH}$ increased very slowly after liming, with a noticeable increase being in January 2001 (second 
Table 4 Temporal evolution of soil parameters after liming (in situ), site of Navasfrías (0-10 cm)

\begin{tabular}{|c|c|c|c|c|c|c|c|c|c|}
\hline \multirow{2}{*}{$\begin{array}{l}\text { Navasfrías (Spain) } \\
\text { Soil sample 0-10 cm } \\
\text { Dates }\end{array}$} & \multicolumn{9}{|c|}{ Limed experimental plot (5th/Sept./99) } \\
\hline & $\begin{array}{l}\text { 1st/ } \\
\text { Dec./99 }\end{array}$ & $\begin{array}{l}\text { 6th/ } \\
\text { June/00 }\end{array}$ & $\begin{array}{l}\text { 18th/ } \\
\text { Jan./01 }\end{array}$ & $\begin{array}{l}\text { 20th/ } \\
\text { June/01 }\end{array}$ & $\begin{array}{l}\text { 27th/ } \\
\text { Nov./01 }\end{array}$ & $\begin{array}{l}\text { 28th/ } \\
\text { Oct./02 }\end{array}$ & $\begin{array}{l}14 \mathrm{th} / \\
\text { Oct./03 }\end{array}$ & $\begin{array}{l}\text { 17th/ } \\
\text { March/05 }\end{array}$ & $\pm \mathrm{SD}$ \\
\hline $\mathrm{pH}(\mathrm{KCl} 1: 2.5)$ & 3.5 & 3.9 & 4.3 & 4.2 & 4.1 & 4.7 & 6.0 & 4.9 & N. d. \\
\hline $\mathrm{pH}\left(\mathrm{H}_{2} \mathrm{O} 1: 2.5\right)$ & 4.6 & 5.0 & 5.5 & 5.4 & 5.2 & 5.8 & 6.5 & 5.9 & \pm 0.1 \\
\hline $\mathrm{CEC}\left(\mathrm{cmol}_{\mathrm{C}} \mathrm{kg}^{-1}\right)$ & 20 & 24 & 30 & 23 & 26 & 20 & 28 & 27 & \pm 4.6 \\
\hline $\mathrm{Ca}^{2+}\left(\mathrm{cmol}_{\mathrm{c}} \mathrm{kg}^{-1}\right)$ & 3.3 & 1.0 & 6.0 & 5.5 & 5.2 & 7.0 & 21.8 & 22.0 & \pm 0.6 \\
\hline $\mathrm{Mg}^{2+}\left(\mathrm{cmol}_{\mathrm{c}} \mathrm{kg}^{-1}\right)$ & 0.5 & 0.4 & 1.8 & 0.8 & 1.2 & 0.6 & 0.8 & 0.6 & \pm 0.2 \\
\hline $\mathrm{K}^{+}\left(\mathrm{cmol}_{\mathrm{c}} \mathrm{kg}^{-1}\right)$ & 0.5 & 0.2 & 0.3 & 0.2 & 0.3 & 0.4 & 0.4 & 0.4 & \pm 0.1 \\
\hline Base saturation (\%) & 22 & 6.7 & 27 & 28 & 26 & 40 & 83 & 85 & \pm 2.8 \\
\hline SOM (\%) & 17 & 12 & 17 & 11 & 16 & 12 & 14 & 11 & \pm 3.5 \\
\hline $\mathrm{SOC}\left(\mathrm{mg} \mathrm{C} \mathrm{g}^{-1}\right)$ & 98 & 70 & 100 & 65 & 90 & 72 & 82 & 65 & \pm 20.1 \\
\hline $\mathrm{N}_{\text {total }}\left(\mathrm{mg} \mathrm{N} \mathrm{g}^{-1}\right)$ & 4.9 & 3.8 & 5.0 & 2.8 & 4.3 & 4.6 & 5.0 & 3.7 & \pm 0.8 \\
\hline $\mathrm{C} / \mathrm{N}$ & 20 & 18 & 20 & 23 & 20 & 16 & 16 & 18 & \pm 2.4 \\
\hline Available $\mathrm{P}\left(\mathrm{mg} \mathrm{P} \mathrm{kg}^{-1}\right)$ & 21 & 8 & 18 & 18 & 11 & 10 & 6 & 9 & \pm 7.3 \\
\hline Available Ca (mg Ca kg-1) & 430 & 700 & 1400 & 593 & 740 & 885 & 4171 & 2980 & N. d. \\
\hline Available K (mg K kg${ }^{-1}$ ) & 166 & 100 & 145 & 131 & 150 & 50 & 165 & 125 & N.d. \\
\hline
\end{tabular}

N.d. no data

Table 5 Temporal evolution of soil parameters after liming (in situ), site of Navasfrías (10-20 cm)

\begin{tabular}{|c|c|c|c|c|c|c|c|c|c|}
\hline \multirow{2}{*}{$\begin{array}{l}\text { Navasfrías (Spain) } \\
\text { Soil sample } 10-20 \mathrm{~cm} \\
\text { Dates }\end{array}$} & \multicolumn{9}{|c|}{ Limed experimental plot (5th/Sept./99) } \\
\hline & $\begin{array}{l}1 \mathrm{st} / \\
\mathrm{Dec} / 99\end{array}$ & $\begin{array}{l}\text { 6th/ } \\
\text { June/00 }\end{array}$ & $\begin{array}{l}\text { 18th/ } \\
\text { Jan/01 }\end{array}$ & $\begin{array}{l}\text { 20th/ } \\
\text { June/01 }\end{array}$ & $\begin{array}{l}\text { 27th/ } \\
\text { Nov/01 }\end{array}$ & $\begin{array}{l}\text { 28th/ } \\
\text { Oct.02 }\end{array}$ & $\begin{array}{l}\text { 14th/ } \\
\text { Oct/03 }\end{array}$ & $\begin{array}{l}\text { 17th/ } \\
\text { March/05 }\end{array}$ & $\pm \mathrm{SD}$ \\
\hline $\mathrm{pH}(\mathrm{KCl} 1: 2.5)$ & 3.8 & 4.1 & 4.2 & 4.2 & 4.1 & 4.2 & 4.7 & 4.5 & N. d. \\
\hline $\mathrm{pH}\left(\mathrm{H}_{2} \mathrm{O} 1: 2.5\right)$ & 4.8 & 5.0 & 5.3 & 5.3 & 5.3 & 5.3 & 5.8 & 5.6 & \pm 0.1 \\
\hline CEC $\left(\mathrm{cmol}_{\mathrm{c}} \mathrm{kg}^{-1}\right)$ & 23 & 21 & 23 & 14 & 22 & 19 & 23 & 27 & \pm 4.6 \\
\hline $\mathrm{Ca}^{2+}\left(\mathrm{cmol}_{\mathrm{c}} \mathrm{kg}^{-1}\right)$ & 0.9 & 0.3 & 1.5 & 0.3 & 0.8 & 1.3 & 8.3 & 5.9 & \pm 0.6 \\
\hline $\mathrm{Mg}^{2+}\left(\mathrm{cmol}_{\mathrm{c}} \mathrm{kg}^{-1}\right)$ & 0.2 & 0.2 & 0.7 & 0.1 & 0.4 & 0.3 & 0.4 & 0.3 & \pm 0.2 \\
\hline $\mathrm{K}^{+}\left(\mathrm{cmol}_{\mathrm{c}} \mathrm{kg}^{-1}\right)$ & 0.4 & 0.1 & 0.2 & 0.1 & 0.2 & 0.2 & 0.3 & 0.2 & \pm 0.1 \\
\hline Base saturation (\%) & 6.5 & 2.0 & 10 & 3.6 & 6.4 & 9.5 & 39 & 24 & \pm 2.8 \\
\hline SOM (\%) & 12 & 11 & 13 & 3.6 & 10 & 10 & 13 & 10 & \pm 3.5 \\
\hline $\mathrm{SOC}\left(\mathrm{mg} \mathrm{C} \mathrm{g}{ }^{-1}\right)$ & 67 & 65 & 75 & 21 & 68 & 58 & 77 & 56 & \pm 20.1 \\
\hline $\mathrm{N}_{\text {total }}\left(\mathrm{mg} \mathrm{N} \mathrm{g}^{-1}\right)$ & 3.9 & 3.5 & 4.2 & 1.2 & 4.4 & 3.3 & 3.9 & 3.5 & \pm 0.8 \\
\hline $\mathrm{C} / \mathrm{N}$ & 17 & 19 & 18 & 18 & 15 & 18 & 20 & 16 & \pm 2.4 \\
\hline Available $\mathrm{P}\left(\mathrm{mg} \mathrm{P} \mathrm{kg}^{-1}\right)$ & 30 & 2 & 8 & 13 & 6 & 4 & 5 & 7 & \pm 7.3 \\
\hline Available Ca (mg Ca kg $\left.{ }^{-1}\right)$ & 280 & 425 & 360 & 161 & 245 & 195 & 964 & 843 & N.d. \\
\hline Available $\mathrm{K}\left(\mathrm{mg} \mathrm{K} \mathrm{kg}^{-1}\right)$ & 117 & 70 & 85 & 37 & 80 & 31 & 110 & 83 & N.d. \\
\hline
\end{tabular}

N.d. no data

winter). The maximum $\mathrm{pH}$ values were reached in October 2003 and, later on, in March 2004 the soil reached the predicted $\mathrm{pH}$ (around 6.0; 3 years after the initial liming), increasing the saturation of the CEC to $85 \%$ in the soil layer $0-10 \mathrm{~cm}$.

A parallel and significant increase in the exchangeable $\mathrm{Ca}^{2+}$ was observed, reaching the maximum value
(22.0 $\left.\mathrm{cmol}_{\mathrm{c}} \mathrm{kg}^{-1}\right)$ in October 2003, as also observed in March 2005 (Tables 4 and 5).

The exchangeable $\mathrm{Mg}^{2+}$ also showed a significant increase, with a faster increase by January 2001 than that observed for $\mathrm{Ca}^{2+}$, the maximum $\mathrm{Mg}^{2+}\left(1.8 \mathrm{cmol}_{\mathrm{c}} \mathrm{kg}^{-1}\right)$ appearing in January 2001, but returning to the initial value at the end of the period considered. 
The values of the exchangeable $\mathrm{K}^{+}$decreased significantly $\left(0.3 \mathrm{cmol}_{\mathrm{c}} \mathrm{kg}^{-1}\right)$ during the first 2 years of experimentation; later, they increased to a value close to the initial one.

The values of the sum of the base fluctuated significantly, parallel to those of the exchangeable $\mathrm{Ca}^{2+}$, affecting the values of the percentage of base saturation as a result (Tables 4,5 ) and giving maximum values after October 2003.

SOC and $\mathrm{N}_{\text {total }}$ contents did not show significant variations, given the high standard deviations of the mean (Table 2); the same observation is pertinent to the $\mathrm{C} / \mathrm{N}$ ratio.

The available P suffered oscillations during the period of study at both depths; a significant increase of available $\mathrm{P}$ was observed after liming (reaching values above $20 \mathrm{mg} \mathrm{P} \mathrm{kg}^{-1}$ ), returning back later to the initial value.

The content of available $\mathrm{Ca}$ increased significantly over time, but without a net pattern, attaining a maximum in October 2003 (4.8 $\mathrm{mg} \mathrm{Ca} \mathrm{g}^{-1}$ ), affecting mainly the first soil layer $(0-10 \mathrm{~cm})$. On the other hand, the available $\mathrm{K}$ did not differ significantly.

\section{Discussion}

\section{Characteristics of the soil studied}

The values of the soil parameters of the control subplot are not limed (Table 1) inside the range of values obtained by Quilchano et al. [28] and Gallardo et al. [9, 27] for the plot studied here.

Quilchano et al. [28] observed high standard deviations for values of SOC, $\mathrm{N}_{\text {total }}$, and $\mathrm{C} / \mathrm{N}$ ratio; the annual fluctuations of these parameters (mainly SOC content) are attributed to the autumnal fall of litter (seasonal organic inputs). The standard deviations for the rest of the parameters are lower and the significant differences observed in the limed subplot in relation to the no-limed one should be attributed to the effect of liming (except for the available $\mathrm{P}$, given that availability of $\mathrm{P}$ is also influenced by other soil properties, as the soil $\mathrm{pH}$, inputs of organic residues, and/or the presence of free sesquioxides[15].

The observed difference of exchangeable $\mathrm{Ca}^{2+}$ between these two soil depths is caused by the effect of the biogeochemical cycle [34, 35].

\section{Suitability of the lime by-product}

Analysis of the lime by-product (originated from the sugar industry) used indicated that it appears technically recommendable because it has a high content of $\mathrm{CaCO}_{3}$ (75\%). Thus, this material is considered suitable for liming acid soils [36], despite having definite hygroscopic characteristics and, hence, tending to clump.

Besides that, $3 \%$ of the impurities of the lime by-product are organic C (Table 2); that is, $5 \%$ of the by-product is organic material. Since the SOC content (referred to $-20 \mathrm{~cm}$ depth) is $103 \mathrm{Mg} \mathrm{C} \mathrm{ha}^{-1}$ [37], an additional contribution of $0.5 \mathrm{MgC} \mathrm{ha}^{-1}$ on the soil surface (as organic residues included in the limestone by-product) does not represent a significant contribution of $\mathrm{C}$, taking into account the slow mineralization of this organic material because of its fibrous nature [37].

\section{Evolution of soil parameters in vitro}

Properties of the forest soil samples (limed in vitro) showed significant increases, especially soil $\mathrm{pH}$, CEC, and exchangeable $\mathrm{Ca}^{2+}$ (Table 3). Rodenkirchen [38] indicated that liming increases the exchangeable $\mathrm{Ca}^{2+}$. The quick increase of the $\mathrm{CEC}$ value indicates that the increase of soil $\mathrm{pH}$ activates immediately negative charges of the CEC (very weak acids; [39]); nevertheless, the methodology of CEC determination (the soil $\mathrm{pH}$ is adjusted to neutrality with ammonium acetate) could partially mask the extent of this increase.

The percentage of base saturation did not appear to be influenced by liming over the short term due to the significant increase of the CEC caused by the liming; nevertheless, the exchangeable $\mathrm{Al}^{3+}$ (which decreased sharply, to be finally undetectable) suffered the desired effect of inactivation (decreasing its toxicity to roots [16]).

The significant decrease of the values of exchangeable $\mathrm{K}^{+}$after liming is probably a result of its displacement caused by the abundant $\mathrm{Ca}^{2+}$ added [39].

\section{Evolution of the soil parameters in situ}

Limed soils incubated in vitro showed more intense changes in soil parameters than those limed on-site.

Comparing our results, in situ vs. in vitro experiments, it is inferred that the characteristics of the sugar beet byproduct (hygroscopicity, particle size, and the method of addition to soil, that is, added on surface) hinders a rapid neutralization of the soil in the experimental plot.

The data of soil $\mathrm{pH}$ and exchangeable $\mathrm{Ca}^{2+}$, observed in the limed plot, lead us to conclude that the liming material dissolved slowly. This was corroborated visually, because the white by-product was observed (not dissolved) on the soil surface until the very rainy winter of 2001.

The low exchangeable $\mathrm{Mg}^{2+}$ content of the lime byproduct dissolved before the $\mathrm{Ca}^{2+}\left(\mathrm{Mg}^{2+}\right.$ is considered a soluble cation), but it also returned most quickly to the initial value (before the end of the field experiment).

The decrease in exchangeable $\mathrm{K}^{+}$observed in situ, should be motivated by the displacement of $\mathrm{K}^{+}$from the exchangeable complex when $\mathrm{Ca}^{2+}$ is added [39], being subsequently leached by rainwater to lower horizons (obviously, this loss of $\mathrm{K}^{+}$cannot occur in the in vitro test). This same phenomenon was also observed by Matzner et al. [2]. 
The erratic behavior observed for available $\mathrm{P}$ is because its bio-availability is affected by different soil factors as indicated before (for example, precipitation by active forms of $\mathrm{Ca}, \mathrm{Fe}$, and/or $\mathrm{Al}$ ); and thus it did not show any clear pattern. It was previously demonstrated that the soil sesquioxides (Fe and $\mathrm{Al}$ ) quickly precipitated the dissolved P $[34,35,40,15]$; as a result of this, it is not possible to improve the availability of soil $\mathrm{P}$ with the sole addition of liming material. Komljenovic et al. [41] found that liming influenced the annual production yields, but so did the climatic factors; given the low dissolution process of the $\mathrm{CaCO}_{3}$ added, it is difficult to think that the dissolved liberated $\mathrm{Ca}^{2+}$ could have more impact than the sesquioxides.

The data obtained during the 6 years of experimentation show that the effect of the lime by-product was only evident after the third year, having its largest impact on the soil parameter related to the exchangeable complex [42]. These results are also consistent with those observed by Matzner et al. [2] in a similar work performed in Germany; their studies found that the superficial application of lime to the forest selected caused an increase of about $20 \%$ in the base saturation value of epipedon after several years, which reduced the risk of $\mathrm{Al}^{3+}$ toxicity.

However, in their study losses of SOC and $N_{\text {total }}(11$ and $14 \%$, respectively, referred to a soil depth of $-30 \mathrm{~cm}$ ) were observed; they also observed that the liming effect on the soil $\mathrm{C}$ and $\mathrm{N}$ obviously was lower when the lime was applied superficially than when incorporated into soil by tillage. Tang et al. [43] found that the liming product was not dissolved until 2 years after it was added to the soil. Furthermore, Bakker et al. [44], analyzing the effect of the gypsum and lime on forest soils, observed that adding $\mathrm{CaO}$ increased the soil $\mathrm{pH}$ as well as the exchangeable $\mathrm{Mg}^{2+}$ and $\mathrm{Ca}^{2+}$, reducing also the exchangeable $\mathrm{Al}^{3+}$ content (mainly in the $A h$ horizon).

The liming impact on the SOM content is insignificant in our experiment, given the high variability of the indicated parameters ( $\mathrm{SOC}, \mathrm{N}_{\text {total }}$, and soil $\mathrm{C} / \mathrm{N}$ ratio), as previously indicated. However, liming affects soil microbial activity, because it is enhanced when the soil $\mathrm{pH}$ increases $[45,46]$, changing the quality of SOM $[18,19]$ and, consequently, the soil $\mathrm{C} / \mathrm{N}$ ratio [47]. Therefore, the liming effect on the $\mathrm{C}$ and $\mathrm{N}$ cycles is clearly dependent on the dissolution rate of the lime product; e.g., a significant part of the Ca could remain as carbonate on the epipedon if there is not enough rainfall. Matzner et al. [2] determined that in their experiment, $50 \%$ of the applied $\mathrm{Ca}$ was found in the organic layer $O$ and another $27 \%$ in the epipedon ( $A_{h}$ horizon).

The no-dissolved $\mathrm{CaCO}_{3}$ was impossible to be quantified in the experimental plot because of the involved difficulties, but the visual observation of the white spots in the forest soil indicated the resistance of the by-product to dissolve. These dots disappeared completely during the wet season of 2002/2003 (from fall to spring), after two rainy winters. Additionally, uninterrupted soil moisture would sustain strong $\mathrm{CO}_{2}$ emission by microbial respiration [37]. Our analyses show that the superficial application of this lime by-product had (Tables 3 and 4), in the short term, a limited effect on the soil $\mathrm{pH}$ of the epipedon (rather concentrated in the top $-10 \mathrm{~cm}$ and weaker further down, i.e., $10-20 \mathrm{~cm})$.

\section{Conclusions}

The main conclusions derived from this study are:

The evolution (in vitro test) of soil $\mathrm{pH}$, after being limed with this lime by-product, was similar to that observed when pure $\mathrm{CaCO}_{3}$ was added, increasing significantly the values of the soil $\mathrm{pH}, \mathrm{CEC}$, and exchangeable $\mathrm{Ca}^{2+}$, and decreasing the exchangeable $\mathrm{Al}^{3+}$ to an undetectable value. Therefore, this lime by-product can be considered potentially valid to correct soil acidity.

However, the liming effect on soil properties of the field forest plot was only detectable after 3 years, mostly conditioned by climatic conditions (the first meteorological cycle was dry, just after the addition of the lime by-product); furthermore, other factors that may have had an adverse influence included the surface lime application (given the limited conditions of forest systems) and the size of granulation (economic reasons do not permit the previous grinding of the lime by-product). As a result, the effect of liming on soil $\mathrm{pH}$ was more gradual than expected (especially, in comparison with results obtained in vitro).

This study shows, once again, that the direct implementation in the field of results obtained in vitro (without complementary experiments on-site to validate the in vitro trials) can lead to significant divergences in results, given the differences in factors and conditions existing between laboratory and the natural conditions.

\section{Authors' contributions}

IMG directed the work done on the field (in situ experiment) and the lab analysis of soil samples; JFG planned the overall experiment and coordinated and drafted the manuscript; JAE directed the work done in the lab (in vitro experiment); JJO performed the initial lab analyses as part of her Master studies abroad. All authors read and approved the final manuscript.

\section{Author details}

${ }^{1}$ Area de Edafología, University of Salamanca, Salamanca 37080, Spain. ${ }^{2}$ C.S.I.C., IRNASa, Cordel de Merinas 40, Salamanca 37080, Spain. ${ }^{3}$ Colegio de Posgraduados, Campus Tabasco, Cardenas, Tabasco, Mexico.

\section{Acknowledgements}

This work was possible thanks to the support received from the European Union (PROTOS/TERI Project) of the Spanish Ministry of Education and Junta de Castilla y León (Spain). The authors point out also their gratitude to M. González and J. Hernández-Pombero for technical help. The authors appreciate the English editing performed by R. M. Buxton. 


\section{Competing interests}

The authors declare that they have no competing interests.

Received: 6 April 2016 Accepted: 7 July 2016

Published online: 13 October 2016

\section{References}

1. Gallardo JF. Biogeochemistry of Mediterranean forest ecosystems: A case study. In: Bollag JM, Stotzky G, editors. Soil Biochemistry, vol. 10. New York: Marcel Dekker; 2000. p. 423-60.

2. Matzner E, Khanna PK, Meiwes KJ, Ulrich B. Effects on fertilization and liming on the chemical soil conditions and element distribution in forest soils. Plant Soil. 1985;87:405-15.

3. Baligar VC, Ahldrichs JL. Nature and distribution of acids soils in the World. In: Schaffert RE, editor. Develop a strategy for collaborative research and dissemination of technology in sustainable crop production. Purdue: Purdue University; 1998. p. 11.

4. Ingerslev M. Effect of liming and fertilization on growth, soil chemistry and soil water chemistry in a Norway spruce plantation on a nutrientpoor soil in Denmark. For Ecol Manage. 1997;92:55-66.

5. Jandl R, Rubio A, Blanco A. Cambios en la química de los suelos forestales de Centroeuropa: Acidifiación y eutrofización. Ecología. 2004;18:285-95.

6. Carvalho JPF, editor. O Carvalho negral. AGRO/U.T.A.D., Vila Real (Portugal); 2005. p. 206.

7. García de Figuerola LC, Rodríguez, L. Bascones MA, Martín D. Mapa geológico de España (1:50.000): Gata. I.G.M.E., Madrid; 1985.

8. Gallardo JF, Martín A, Santa Regina I. Nutrient cycling in deciduous forest ecosystems in the Sierra de Gata mountains. I. Aboveground litter production and potential nutrient return. Ann Sci For. 1998;55:749-69.

9. Gallardo JF, Martín A, Santa Regina I. Nutrient cycling in deciduous forest ecosystems of the 'Sierra de Gata' mountains: II. Nutrient supplies to the soil through both litter and throughfall. Ann Sci For. 1998;55:771-84.

10. Quilchano C, Haneklaus S, Gallardo JF, Schung E, Moreno G. Sulphur balance in a roadleaf, non polluted, forest ecosystem (Central-Western Spain). For Ecol Manag. 2002;161:205-14

11. Robinson JB, Helyar KR. Simulating the impact of acidifying farming systems on Australian soils. Ecol Model. 1996:86:207-11.

12. Mäkelä M, Watkins G, Pöykiö R, Nurmesniemi H, Dahl O. Utilization of steel, pulp and paper industry solid residues in forest soil amendment: relevant physicochemical properties and heavy metal availability. J Hazard Mater. 2012;207-208:21-7.

13. Moreno G, Gallardo JF. Atmosferic deposition in oligotraphic Quercus pyrenaica forest: implications for forest nutrition. For Ecol Manag. 2002;171:17-29.

14. Turrión MB, Gallardo JF, González MI. Extraction of soil-available phosphate, nitrate, and sulphate ions using ion exchange membranes and determination by ion exchange chromatography. Soil Sci Plant Anal. 1999:30:1137-52

15. Turrión MB, Gallardo JF, González MI. Distribution of P forms in natural and fertilized forest soils of the Central Western Spain: plant response to superphosphate fertilization. Arid Soil Res Rehabil. 2000;14:159-73.

16. Runge M, Rode MW. Effects of soil acidity on plant association. In: Ulrich B, Sumner ME, editors. soil acidity. Berlin: Springer; 1991. p. 183-202.

17. Bakker MR, Nys C. Effects on lime-induced differences in site fertility on fine roots of oak. Ann For Sci. 1999;56:599-606.

18. Jokubauskaite I, Slepetiene A, Karcauskiene D. Influence of different fertilization on the dissolved organic carbon, nitrogen and phosphorus accumulation in acid and limed soils. Eurasian J Soil Sci. 2015;4(2):137-43.

19. Rineau F, Maurice JP, Nys C, Voiry H, Garbaye J. Forest liming durably impact the communities of ectomycorrhizas and fungal epigeous fruiting bodies. Ann For Sci. 2010;67:110-12.

20. Cabral F, Ribeiro HM, Hilário M, Machado L, Vasconselos E. Use of pulp mil inorganic wastes as alternative liming materials. Bioresour Thecnol. 2008;99:8294-9298

21. Nurmesniemi H, Mäkelä M, Pöykiö R, Manskinen K, Dahl O. Comparison of the forest fertilizer properties of ash fractions from two power plants of pulp and paper mills incinerating biomass-based fuels. Fuel Process Technol. 2012;104:1-6.
22. Peregrina F, González P, Espejo R, Santano J. Agronomic implications of the supply of lime and gypsum by-products to palexerults from Western Spain. Soil Sci. 2006;171(1):65-81.

23. Pöykiö R, Nurmesniemi H. Calcium carbonate waste from an integrated pulp and paper mill as a potential liming agent. Environm Chem Lett. 2008:6:47-51

24. EPA. 2007. The Use of Soil Amendments for Remediation, Revitalization and Reuse. Docu. 542-R-07-013, U.S. E.P.A., https://clu-in.org/download/ remed/epa-542-r-07-013.pdf. Accessed Dec 2007.

25. WRB-FAO. World Reference Base for Soil Resources. 2nd edn. FAO-ISRICIUSS, World Soil Resources Reports, No.103. F.A.O., Rome; 2006. p. 128.

26. Soil Taxonomy Staff. Soil taxonomy: a basic system of soil classification for making and interpreting soil surveys. 11th edn. Washington DC: Natural Resources Conservation Service, USDA; 2010

27. Gallardo JF, Egido JA, González MI, Santa Regina I, Moreno G, Quilchano C, Gallego H, Martín A, Menéndez I, Schneider K, Turrión MB. Ciclos de nutrientes en bosques experimentales de Quercus pyrenaica Will. Diseño experimental y resultados (Sierra de Gata, provincia de Salamanca). Stvdia Oecol. 1995;12:123-42.

28. Quilchano C, Egido JA, González MI. Comparative soil study in a Mediterranean ecosystem of Quercus pyrenaica Willd. Geomicrobiol J. 1995:13:265-79.

29. Guitián F, Carballas T. Técnicas de análisis de suelos. 2nd ed. Santiago de Compostela: Editorial Pico-Sacro; 1976.

30. Cochrane T, Salinas J, Sánchez P. An equation for liming acid mineral soils to compensate crops aluminum tolerance. Tropical Agriculture. 1980:57:133-40.

31. Mroz GD, Reed DD. Forest soil sampling efficiency: matching laboratory analysis and field sampling procedures. Soil Sci Soc Am J. 1991;55:1413-6.

32. Black CA, Evans DD, White UL, Ensminger LE, Clark FE. Methods for soil analysis. Part I, Agronomy, S.S.A., Madison, vol 2; 1965. p. 1770.

33. Bray RH, Kurtz LT. Determination of total, organic, and available forms of phosphorus in soils. Soil Sci. 1945;59:39-45.

34. Gallardo JF, Cuadrado S, Egido JA. Suelos forestales del El Rebollar (Salamanca). II: Propiedades y conclusiones. Anu Cent Edaf Biol Apli. 1980;6:214-28

35. Gallardo JF, Egido JA, Prat L. Suelos forestales de El Rebollar (Salamanca). I: consideraciones generales. Anu Cent Edaf Biol Apli. 1980;6:193-213.

36. Londoño DH. Acidez y encalamiento de los suelos. 2a ed. Medellín (Colombia): I.C.O.L. y Cía; 2000

37. Martín A, Gallardo JF, Santa Regina I. Long-term decomposition process of leaf litter from Quercus pyrenaica forests across a rainfall gradient (Spanish Central System). Ann Sci For. 1997:54:191-202.

38. Rodenkirchen $\mathrm{H}$. Evidence for a nutritional disorder of Oxalis acetocella L. on acid forest soils. I. Control situation and effects of dolomitic liming and acid irrigation. Plant Soil. 1998;199:141-52.

39. Bonneau M, Souchier B. Edafología: Constituyentes y propiedades del suelo, vol. 2. Barcelona: Masson; 1987. p. 462

40. Gallardo JF, González MIM. Suelos forestales de El Rebollar. III: nuevas aportaciones. Anu Cent Edaf Biol Apli. 1983:9:223-32.

41. Komljenovic I, Markovica M, Djurasinovicb G, Kovacevic V. Response of maize to liming and ameliorative phosphorus fertilization. Adv Crop Sci. 2013;3(3):225-32.

42. Fransson AM, Bergkvist $B$, Tyler G. Phosphorus solubility in an acid forest soil as influenced by form of applied phosphorus and liming. Scand J For Res. 1999:14:538-44.

43. Tang C, Rengel Z, Diatloff E, Gazey C. Responses of wheat and barley to liming on a sandy soil and with subsoil acidity. Field Crop Res. 2003:80:235-44.

44. Bakker MR, Nys C, Picard JF. The effects on liming and gypsum applications on a sessile oak (Quercus petraea (M.) Liebl.) stand at Lacroix-Scaille (French Ardennes) I. Site characteristics, soil chemistry and aerial biomass. Plant Soil. 1998;206:99-108.

45. Dommergues Y, Mangenot F. Ecologie microbienne des sols. Paris: Masson; 1970. p. 796

46. Neale SP, Shah Z, Adams WA. Changes in microbial biomass and N turnover in acidic organic soils following liming. Soil Biol Biochem. 1997;29(9):1463-74.

47. Russell EJ. Soil conditions and plant growth. 11 th ed. New Delhi: Delhi Biotech; 2002. 